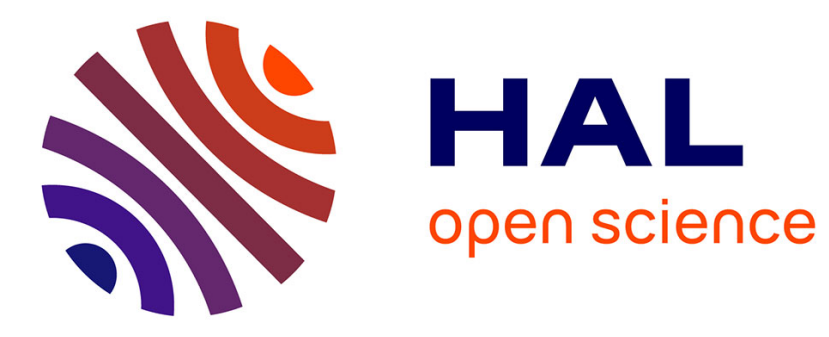

\title{
Zirconia-spinel composites. Part II: mechanical properties
}

Olivier Quénard, Christophe Laurent, Alain Peigney, Abel Rousset

\section{To cite this version:}

Olivier Quénard, Christophe Laurent, Alain Peigney, Abel Rousset. Zirconia-spinel composites. Part II: mechanical properties. Materials Research Bulletin, 2000, vol. 35, pp. 1979-1987. 10.1016/S00255408(00)00409-8 . hal-00949036

\section{HAL Id: hal-00949036 https://hal.science/hal-00949036}

Submitted on 19 Feb 2014

HAL is a multi-disciplinary open access archive for the deposit and dissemination of scientific research documents, whether they are published or not. The documents may come from teaching and research institutions in France or abroad, or from public or private research centers.
L'archive ouverte pluridisciplinaire HAL, est destinée au dépôt et à la diffusion de documents scientifiques de niveau recherche, publiés ou non, émanant des établissements d'enseignement et de recherche français ou étrangers, des laboratoires publics ou privés. 


\section{OATAO \\ Open Archive Toulouse Archive Ouverte}

\section{Open Archive TOULOUSE Archive Ouverte (OATAO)}

OATAO is an open access repository that collects the work of Toulouse researchers and makes it freely available over the web where possible.

This is an author-deposited version published in : http://oatao.univ-toulouse.fr/ Eprints ID : 10981

To link to this article : doi:10.1016/S0025-5408(00)00409-8

URL : http://dx.doi.org/10.1016/S0025-5408(00)00409-8

To cite this version : Quénard, Olivier and Laurent, Christophe and Peigney, Alain and Rousset, Abel Zirconia-spinel composites. Part II: mechanical properties. (2000) Materials Research Bulletin, vol. 35 ( ${ }^{\circ}$ 12). pp. 1979-1987. ISSN 0025-5408

Any correspondance concerning this service should be sent to the repository administrator: staff-oatao@ listes-diff.inp-toulouse.fr 


\title{
Zirconia-spinel composites. Part II: mechanical properties
}

\author{
O. Quénard, Ch. Laurent*, A. Peigney, A. Rousset \\ CIRIMAT, UMR CNRS 5085/LCMIE, Centre Interuniversitaire de Recherche et d'Ingénierie des Matériaux, \\ Université Paul-Sabatier, 31062 Toulouse Cedex 4, France
}

\begin{abstract}
The mechanical properties (fracture strength, fracture toughness, and Vickers microhardness) of $\mathrm{MgAl}_{2} \mathrm{O}_{4}$ and $\mathrm{x}$ wt $\% \mathrm{ZrO}_{2}-\mathrm{MgAl}_{2} \mathrm{O}_{4}(1 \leq \mathrm{x} \leq 30)$ hot-pressed materials were measured at room temperature. Two kinds of materials, which were prepared from either ball-milled or attrited powders, were investigated. Compared with an unreinforced spinel, a twofold (or greater) increase in both strengthening and toughening was measured for materials with the highest zirconia content (30 wt $\%$ ). It was found that dispersing only $1 \mathrm{wt} \%$ of zirconia in the spinel produced a marked increase in the Vickers microhardness. The total zirconia content appears to be a key parameter. (C) 2001 Elsevier Science Ltd. All rights reserved.
\end{abstract}

Keywords: A. Oxides; A. Composites; C. Electron microscopy; D. Microstructure, D. Mechanical properties

\section{Introduction}

The field of applications of the spinel $\mathrm{MgAl}_{2} \mathrm{O}_{4}$ is limited by its poor mechanical properties at room temperature [1-8]. The dispersion of micrometric $\mathrm{ZrO}_{2}$ particles as a discrete second phase is a well-known method for the enhancement of the mechanical properties of ceramics [9]. Several reinforcement mechanisms have been identified, including microcracking, owing to the transformation upon cooling from the sintering temperature of tetragonal $\mathrm{ZrO}_{2}\left(\mathrm{t}-\mathrm{ZrO}_{2}\right)$ particles into monoclinic $\mathrm{ZrO}_{2}\left(\mathrm{~m}-\mathrm{ZrO}_{2}\right)$ particles (denoted hereafter as the $\mathrm{t} \rightarrow \mathrm{m}$ transformation), stress-induced $\mathrm{t} \rightarrow \mathrm{m}$ transformation, compressive

* Corresponding author. Tel.: +33-561-55-61-22; Fax: +33-561-55-61-63.

E-mail address: laurent@iris.ups-tlse.fr (Ch. Laurent). 
surface stresses, crack branching, and crack deflection. However, most studies have dealt with $\mathrm{ZrO}_{2}-\mathrm{Al}_{2} \mathrm{O}_{3}$ composites [9], and only a few with $\mathrm{ZrO}_{2}-\mathrm{MgAl}_{2} \mathrm{O}_{4}$ composites [10-12].

Claussen and Rühle [10] reported that the fracture strength of $\mathrm{MgAl}_{2} \mathrm{O}_{4}$ increases from 200 to $500 \mathrm{MPa}$ upon the dispersion of $25 \mathrm{wt} \% \mathrm{ZrO}_{2}$, with $60 \%$ of the total $\mathrm{ZrO}_{2}$ content being in the metastable tetragonal form and $40 \%$ in the monoclinic form. Fujita et al. [11] prepared dense specimens (relative density $\geq 95 \%$ ) by conventional sintering or hot pressing of powders of spinel and a $24 \mathrm{wt} \% \mathrm{ZrO}_{2}-$ spinel composite synthesized by the powder mixing and alkoxides routes. In these materials, the spinel is alumina rich $\left(\mathrm{MgO}: \mathrm{Al}_{2} \mathrm{O}_{3}\right.$ ratio equal to $3: 4$ ). The matrix grain size is close to $2 \mu \mathrm{m}$ in both the sintered (ex-alkoxide) spinel and $\mathrm{ZrO}_{2}$-spinel materials, and the average size of the $\mathrm{ZrO}_{2}$ particles is $0.5 \mu \mathrm{m}$. The fracture strength and the fracture toughness of the composite $\left(400 \mathrm{MPa}\right.$ and $\left.6.3 \mathrm{MPa} \cdot \mathrm{m}^{1 / 2}\right)$ are about twice those measured for the unreinforced spinel (230 $\mathrm{MPa}$ and $3.1 \mathrm{MPa} \cdot \mathrm{m}^{1 / 2}$ ). For the hot-pressed (expowder mixing) materials, the matrix grain size is close to $4-5 \mu \mathrm{m}$ in the spinel and much smaller $(1.2 \mu \mathrm{m})$ in the composite. The fracture strength increases from 200 $\mathrm{MPa}$ for the spinel to $340 \mathrm{MPa}$ for the composite. These authors [11] proposed that the improvement of the mechanical properties was due to the stress-induced $\mathrm{t} \rightarrow \mathrm{m}$ transformation, higher densification by $\mathrm{ZrO}_{2}$ addition, and inhibition of the matrix grain growth. Hyun and Song [12] prepared a $20 \mathrm{wt} \% \mathrm{ZrO}_{2}$-spinel sintered composite (relative density = $97.8 \%$ ) consisting of a spinel matrix (grain size $=1.5-2 \mu \mathrm{m}$ ) containing $1-2 \mu \mathrm{m}$ cubic $\mathrm{ZrO}_{2}$ $\left(\mathrm{c}-\mathrm{ZrO}_{2}\right)$ agglomerates made up of much smaller primary grains. The fracture strength and the fracture toughness of the composite were equal to $390 \mathrm{MPa}$ and $1.98 \mathrm{MPa} \cdot \mathrm{m}^{1 / 2}$, respectively. The absence of toughening with respect to a spinel produced by the same process was attributed to the presence of $\mathrm{c}-\mathrm{ZrO}_{2}$ rather than $\mathrm{t}-\mathrm{ZrO}_{2}$ particles.

The present authors have reported in a companion paper [13] the synthesis of $\mathrm{MgAl}_{2} \mathrm{O}_{4}$ and $\mathrm{x}$ wt $\% \mathrm{ZrO}_{2}-\mathrm{MgAl}_{2} \mathrm{O}_{4}(1 \leq \mathrm{x} \leq 30)$ powders by the urea combustion route, and the subsequent preparation of dense materials by hot pressing. The aim of the present work is to investigate the mechanical properties (fracture strength, fracture toughness, and Vickers microhardness) of these materials.

\section{Experimental}

$\mathrm{MgAl}_{2} \mathrm{O}_{4}$ and $\mathrm{x}$ wt $\% \mathrm{ZrO}_{2}-\mathrm{MgAl}_{2} \mathrm{O}_{4}(\mathrm{x}=1,5,10,20$, and 30) composite powders were prepared by the urea combustion route [13]. For each composition, the so-obtained powders were separated into two parts, which were ground either by ball milling or by attrition. These powders were uniaxially hot pressed in graphite dies at $1500^{\circ} \mathrm{C}$ in a primary vacuum. The hot-pressed specimens ( $20 \mathrm{~mm}$ in diameter and $2 \mathrm{~mm}$ thick) were ground to a finish finer than $6 \mu \mathrm{m}$ with diamond suspensions, and a final polish was made using "colloidal" silica (0.05 $\mu \mathrm{m})$. Relative densities were calculated from the mass and dimensions of the hot-pressed composites. For the sake of brevity, the materials issued from the hot pressing of ball-milled and attrited powders will be denoted BM0, BM1, .., BM30 and A0, A1, .., A30, respectively, the number reflecting the $\mathrm{ZrO}_{2}$ weight content. The specimens were observed by scanning electron microscopy (SEM). The Vickers microhardness was measured by indentation during $20 \mathrm{~s}$ using a $3 \mathrm{~N}$ load. The values given for $\mathrm{H}_{\mathrm{v}}$ are the average of 10 
Table 1

Some characteristics of the $\mathrm{ZrO}_{2}-\mathrm{MgAl}_{2} \mathrm{O}_{4}$ hot-pressed specimens

\begin{tabular}{llllllll}
\hline Specimen $^{\mathrm{a}}$ & $\mathrm{d}_{\mathrm{r}}$ & $\mathrm{t}-\mathrm{ZrO}_{2}$ & $\varnothing_{\mathrm{s}}$ & $\varnothing_{\mathrm{z}}$ & $\sigma_{\mathrm{f}}$ & $\mathrm{K}_{\mathrm{Ic}}$ & $\mathrm{H}_{\mathrm{v}}$ \\
\hline BM0 & 96.2 & - & 1.4 & - & 259 & 3.3 & 1444 \\
BM1 & 96.5 & 100 & 0.8 & $\mathrm{n}^{\mathrm{m}} \mathrm{m}^{\mathrm{b}}$ & 300 & 3.0 & 1561 \\
BM5 & 95.7 & 84 & 0.8 & 0.19 & 329 & 3.2 & 1584 \\
BM10 & 98.3 & 89 & 0.8 & 0.25 & 294 & 3.0 & 1587 \\
BM20 & 96.9 & 87 & 0.8 & 0.36 & 355 & 4.8 & 1559 \\
BM30 & 96.7 & 48 & 0.8 & 0.44 & 578 & 6.6 & 1575 \\
A0 & 95.5 & - & 0.3 & - & 243 & 2.3 & 1494 \\
A1 & 95.7 & 100 & 0.3 & $\mathrm{n}-\mathrm{m}$ & 234 & 2.8 & 1632 \\
A5 & 96.6 & 88 & 0.3 & 0.35 & 376 & 3.1 & 1617 \\
A10 & 95.8 & 89 & $\mathrm{n}-\mathrm{m}$ & 0.37 & 445 & 3.4 & 1560 \\
A20 & 96.4 & 60 & 0.2 & 0.42 & 489 & 4.0 & 1590 \\
A30 & 94.8 & 19 & $\mathrm{n}-\mathrm{m}$ & 0.44 & 506 & 6.6 & 1505 \\
\hline
\end{tabular}

$\mathrm{d}_{\mathrm{r}}$ : relative density; $\mathrm{t}-\mathrm{ZrO}_{2}$ : proportion $(\%)$ of tetragonal zirconia with respect to the total amount of $\mathrm{ZrO}_{2} ; \varnothing_{\mathrm{s}}$ and $\varnothing_{\mathrm{z}}$ : average size $(\mu \mathrm{m})$ of the spinel grains and of the $\mathrm{ZrO}_{2}$ particles, respectively; $\sigma_{\mathrm{f}}$ : fracture strength (MPa); $\mathrm{K}_{\mathrm{Ic}}$ : fracture toughness $\left(\mathrm{MPa} \cdot \mathrm{m}^{1 / 2}\right) ; \mathrm{H}_{\mathrm{v}}$ : Vickers microhardness.

${ }^{\mathrm{a}} \mathrm{BM}$ and $\mathrm{A}$ denote specimens issued from hot-pressing of ball-milled and attrited powders, respectively, and the number indicates the $\mathrm{ZrO}_{2}$ content in wt $\%$.

${ }^{\mathrm{b}} \mathrm{n}-\mathrm{m}$ : not measured.

measurements. The transverse fracture strength $\left(\sigma_{\mathrm{f}}\right)$ was determined by the three-point bending test on parallelepipedic specimens $\left(1.6 \times 1.6 \times 18 \mathrm{~mm}^{3}\right)$ machined with a diamond saw. The fracture toughness $\left(\mathrm{K}_{\mathrm{Ic}}\right)$ was measured by the SENB method on similar specimens notched using a diamond wire $0.1 \mathrm{~mm}$ in diameter. The calibration factor proposed by Brown and Srawley [14] was used to calculate the SENB toughness from the experimental results. Crosshead speed was fixed at $0.1 \mathrm{~mm} / \mathrm{min}$. The values given for $\sigma_{\mathrm{f}}$ and $\mathrm{K}_{\mathrm{Ic}}$ are the average of measurements on 10 and 6 specimens, respectively.

\section{Results and discussion}

It has been shown [13] that the matrix of the BM specimens is the stoichiometric spinel, whereas that of the A materials is an alumina-rich spinel, the formula of which could be $\mathrm{Mg}_{0.91} \square_{0.03} \mathrm{Al}_{2.06} \mathrm{O}_{4}$. Because it is expected that the effects of the nonstoichiometry are negligible at room temperature [7,15], the oxide in the A materials will be considered as being $\mathrm{MgAl}_{2} \mathrm{O}_{4}$ in the following. The microstructural characteristics of the specimens [13] are listed in Table 1. Both $\mathrm{t}-\mathrm{ZrO}_{2}$ and $\mathrm{m}-\mathrm{ZrO}_{2}$ are present in the composites, except in BM1 and $\mathrm{A} 1$, in which only $\mathrm{t}-\mathrm{ZrO}_{2}$ was detected. The proportion of $\mathrm{t}-\mathrm{ZrO}_{2}$ slightly decreases to a value close to $85 \%$ for BM5, BM10, and BM20, and sharply decreases upon further addition of $\mathrm{ZrO}_{2}$ (48\% for BM30). A similar evolution is observed for the A composites, but it is noteworthy that the sharp decrease of the $\mathrm{t}-\mathrm{ZrO}_{2}$ proportion takes place for a lower $\mathrm{ZrO}_{2}$ content (60\% for A20). SEM observations [13] have shown that the spinel grains are larger in the $\mathrm{BM}$ composites than in the A specimen, and that the presence of $\mathrm{ZrO}_{2}$ particles inhibits the growth of the matrix grains upon hot pressing only in the BM composites $\left(\varnothing_{\mathrm{s}}\right.$ in Table 
1). The $\mathrm{ZrO}_{2}$ particles are homogeneously dispersed at the grain boundaries or grain junctions of the matrix. For both the BM and A specimens, their average size $\varnothing_{\mathrm{z}}$ in Table 1) increases with the total $\mathrm{ZrO}_{2}$ content, but the values are generally higher for the $\mathrm{A}$ materials because the gathering of the $\mathrm{ZrO}_{2}$ particles is easier when the matrix grains are smaller. The $\mathrm{t} \rightarrow \mathrm{m}$ phase transformation occurs for the larger $\mathrm{ZrO}_{2}$ particles upon cooling from the hot-pressing temperature. Thus, the increasing proportion of $\mathrm{m}-\mathrm{ZrO}_{2}$ upon the increase in the total amount of $\mathrm{ZrO}_{2}$, and when comparing BM20 to A20 and BM30 to A30, reflects the growth of the $\mathrm{ZrO}_{2}$ particles. The hypothesis that polishing could have provoked the $\mathrm{t} \rightarrow \mathrm{m}$ phase transformation of $\mathrm{ZrO}_{2}$ particles located at the surface of the materials was ruled out, because it has been verified that the proportion of $\mathrm{m}-\mathrm{ZrO}_{2}$ is similar in the unground, $6 \mu \mathrm{m}$-ground, and silica-polished specimens.

The evolution of $\mathrm{H}_{\mathrm{v}}$ vs. the $\mathrm{ZrO}_{2}$ content is different for the $\mathrm{BM}$ and A composites (Fig. 1 and Table 1). Indeed, $\mathrm{H}_{\mathrm{v}}$ increases from 1444 for $\mathrm{BM} 0$ to a value that remains quite constant (in the 1560-1590 range) regardless of the $\mathrm{ZrO}_{2}$ content of the $\mathrm{BM}$ specimens (Fig. 1a). $\mathrm{ZrO}_{2}$ particles at the matrix grain junctions could minimize the matrix grain slide and thus account for the higher Vickers microhardness, even for a very low zirconia content (1 wt $\%) . \mathrm{H}_{\mathrm{v}}$ for $\mathrm{A} 0$ is close to that measured for BM0 (1494 vs. 1444, respectively), indicating that the matrix grain size has little influence on the microhardness of the present spinel materials. The presence of $1 \mathrm{wt} \% \mathrm{ZrO}_{2}$ leads to a strong increase in microhardness $\left(\mathrm{H}_{\mathrm{v}}=\right.$ 1632 for A1), but, contrary to what is observed for the BM specimens, $H_{v}$ decreases from 1632 to 1505 upon a further increase in $\mathrm{ZrO}_{2}$ content (Fig. 2b). Because this decrease is very important for the composite with the lesser amount of $\mathrm{t}-\mathrm{ZrO}_{2}(\mathrm{~A} 30$, which has a microhardness similar to that of $\mathrm{A} 0$ ), it is proposed that the decrease is caused by the increase in the density of microcracks, which are generated by the volume expansion of the zirconia particles that undergo the $\mathrm{t} \rightarrow \mathrm{m}$ transformation upon cooling from the hot-pressing temperature.

The fracture strength and fracture toughness measured for BM0 and the BM composites are reported in Table 1 and Fig. 2. For BM1, BM5, and BM10, the fracture strength (Fig. 2a) is only marginally higher than that of BM0 $(259 \mathrm{MPa})$, whereas for BM20 and notably for BM30 it is significantly higher (355 MPa and $578 \mathrm{MPa}$, respectively). The evolution of the fracture toughness (Fig. 2b) is similar, with no toughening being observed for BM1, BM5, and BM10, while $\mathrm{K}_{\mathrm{Ic}}$ increases to 4.8 and $6.6 \mathrm{MPa} \cdot \mathrm{m}^{1 / 2}$ for BM20 and BM30, respectively. For the A materials (Fig. 3 and Table 1), it is noteworthy that comparable strengthening and toughening are observed at a lower $\mathrm{ZrO}_{2}$ content than that of the $\mathrm{BM}$ specimens. The fracture strength increases from $243 \mathrm{MPa}$ for A0 to $506 \mathrm{MPa}$ for A30 (Fig. 3a), whereas $\mathrm{K}_{\mathrm{Ic}}$ increases from 2.3 MPa $\cdot \mathrm{m}^{1 / 2}$ for A0 to $6.6 \mathrm{MPa} \cdot \mathrm{m}^{1 / 2}$ for A30 (Fig. 3b).

The fracture strength of BM0 (255 MPa) is similar to that of A0 (243 MPa). These values are of the order of, but slightly higher than, those reported by other workers [7,10,11]. It is noteworthy that $\mathrm{K}_{\mathrm{Ic}}$ for BM0 is higher $\left(3.3 \mathrm{MPa} \cdot \mathrm{m}^{1 / 2}\right)$ than most values $\left(1.3-2.2 \mathrm{MPa} \cdot \mathrm{m}^{1 / 2}\right.$ ) reported for $\mathrm{MgAl}_{2} \mathrm{O}_{4}$ [2-5]. The difference could arise from a smaller matrix grain size in the present material $(1.4 \mu \mathrm{m})$ than in the other materials $(2-400 \mu \mathrm{m})$, because spinels with a grain size lower than $2 \mu \mathrm{m}$ have been found to have a fracture toughness close to 3.3 $\mathrm{MPa} \cdot \mathrm{m}^{1 / 2}[7,11]$. However, a still lower grain size in $\mathrm{A} 0(0.3 \mu \mathrm{m})$ results in a fracture toughness of only $2.2 \mathrm{MPa} \cdot \mathrm{m}^{1 / 2}$. The higher toughness measured for BM0 could result from 

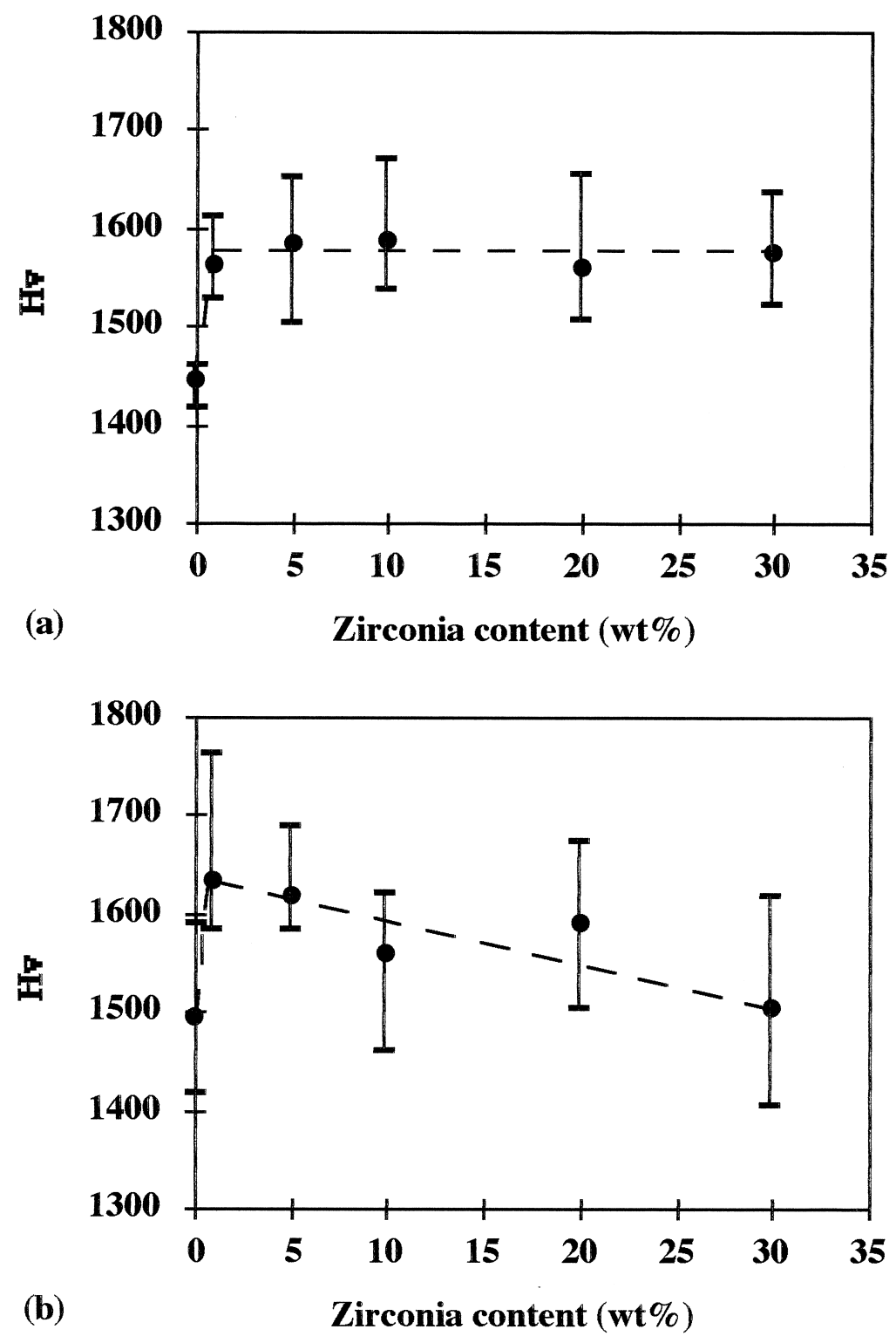

Fig. 1. Vickers microhardness $\mathrm{H}_{\mathrm{v}}$ of the (a) BM and (b) A composites. Bars represent the minimum and maximum values. The dashed lines are guides to the eye.

the mixture of transgranular and intergranular fractures, as revealed by SEM observations presented later in this paper, in contrast to an almost totally intergranular fracture for A0.

The fracture strengths of the BM30 (578 MPa) and A30 (506 MPa) composites are higher than those reported by Claussen and Rühle [10] for a $25 \mathrm{wt} \% \mathrm{ZrO}_{2}-\mathrm{MgAl}_{2} \mathrm{O}_{4}$ specimen $(500$ $\mathrm{MPa}$ ) and that reported by Fujita et al. [11] for a $24 \mathrm{wt} \% \mathrm{ZrO}_{2}-\mathrm{MgAl}_{2} \mathrm{O}_{4}$ composite (400 $\mathrm{MPa}$ ). This could reflect the higher $\mathrm{ZrO}_{2}$ content $(30 \mathrm{wt} \%$ ) in the present composites. Nevertheless, even for lower $\mathrm{ZrO}_{2}$ content (10 and $20 \mathrm{wt} \%$ ), the present A composites 

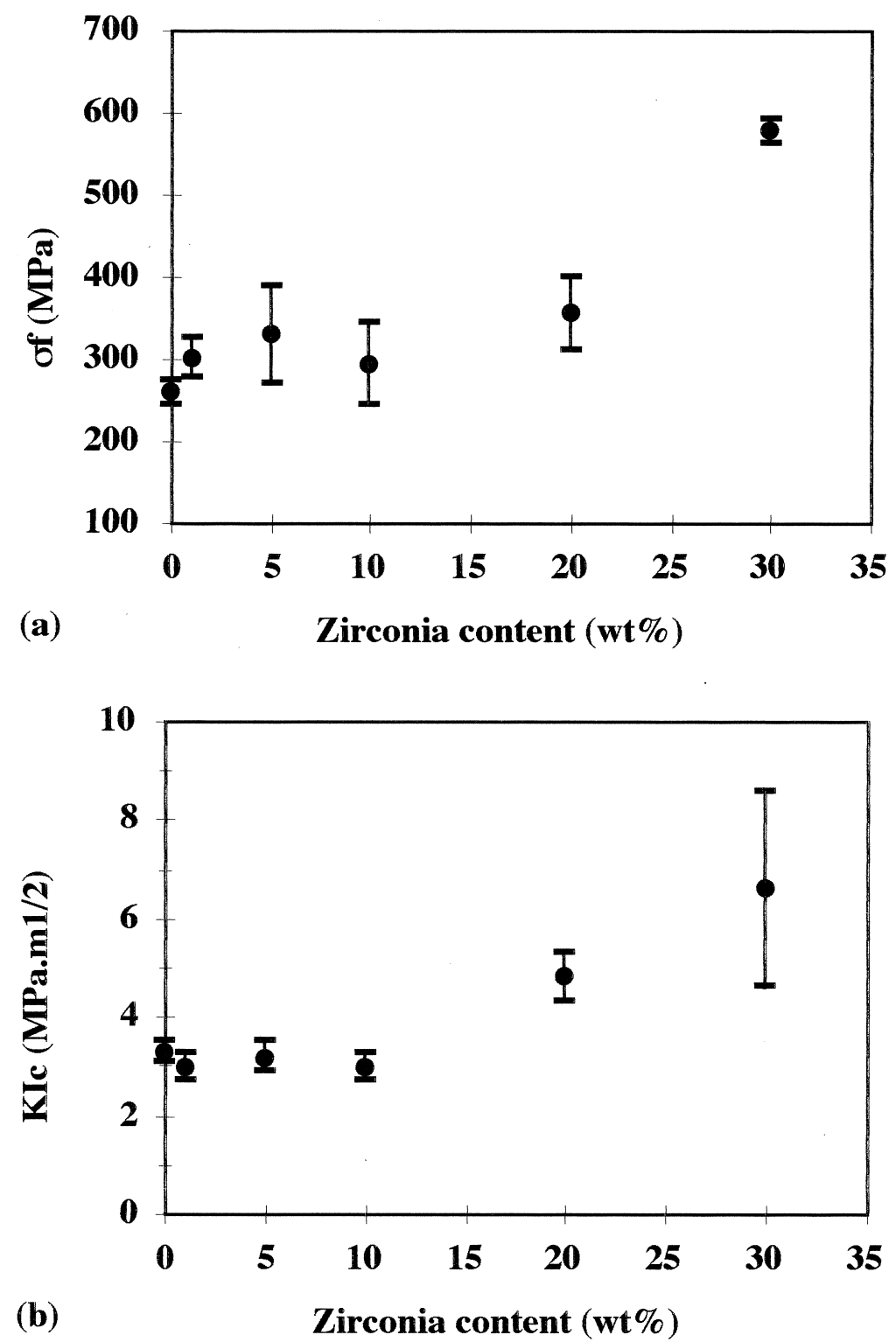

Fig. 2. (a) Fracture strength $\sigma_{\mathrm{f}}$ and (b) fracture toughness $\mathrm{K}_{\mathrm{Ic}}$ of the $\mathrm{BM}$ composites. Bars represent the minimum and maximum values.

exhibit a higher fracture strength (445 and $489 \mathrm{MPa}$, respectively) than the previously reported [11] $24 \mathrm{wt} \% \mathrm{ZrO}_{2}-\mathrm{MgAl}_{2} \mathrm{O}_{4}$ specimen. The fracture toughness for both $\mathrm{BM} 30$ and A30 (6.6 $\left.\mathrm{MPa} \cdot \mathrm{m}^{1 / 2}\right)$ are slightly higher than those reported by Fujita et al. [11] (6.3 $\left.\mathrm{MPa} \cdot \mathrm{m}^{1 / 2}\right)$.

The observation that the highest reinforcement is achieved with the composites that contain the highest quantity of zirconia but also the lowest proportion of $\mathrm{t}-\mathrm{ZrO}_{2}$ suggests that 

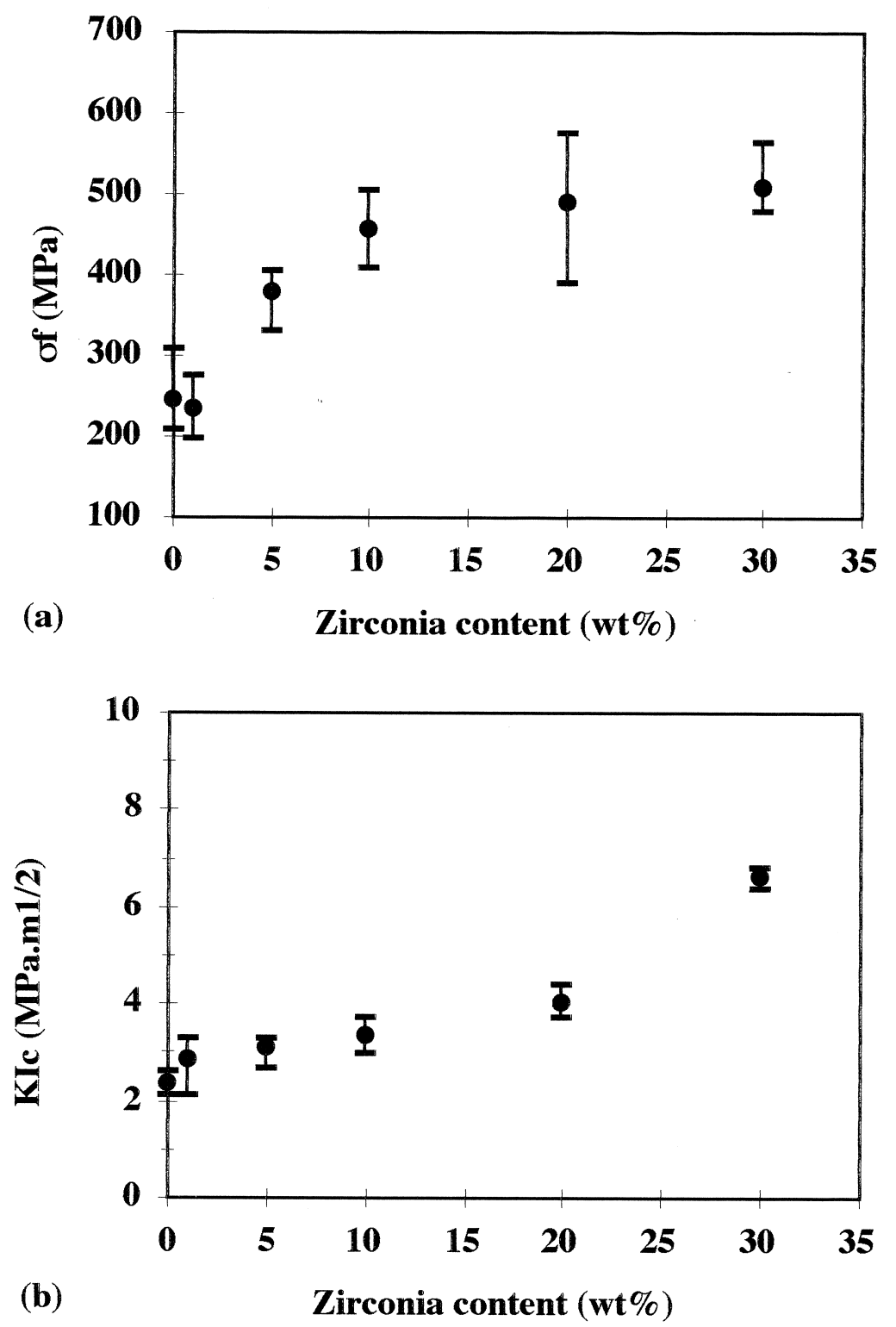

Fig. 3. (a) Fracture strength $\sigma_{\mathrm{f}}$ and (b) fracture toughness $\mathrm{K}_{\mathrm{Ic}}$ of the A composites. Bars represent the minimum and maximum values.

several reinforcement mechanisms occur. The presence of $\mathrm{m}-\mathrm{ZrO}_{2}$ and $\mathrm{t}-\mathrm{ZrO}_{2}$ in the hot-pressed materials indeed points towards both the microcracking and stress-induced $\mathrm{t} \rightarrow$ $\mathrm{m}$ transformation mechanisms being active simultaneously. This is in agreement with results obtained on $\mathrm{ZrO}_{2}-\mathrm{Al}_{2} \mathrm{O}_{3}$ composites [16,17]. The hypothesis that polishing could have provoked the $\mathrm{t} \rightarrow \mathrm{m}$ phase transformation of $\mathrm{ZrO}_{2}$ particles located at the surface of the materials was ruled out, because it has been verified that the proportion of $\mathrm{m}-\mathrm{ZrO}_{2}$ is similar 

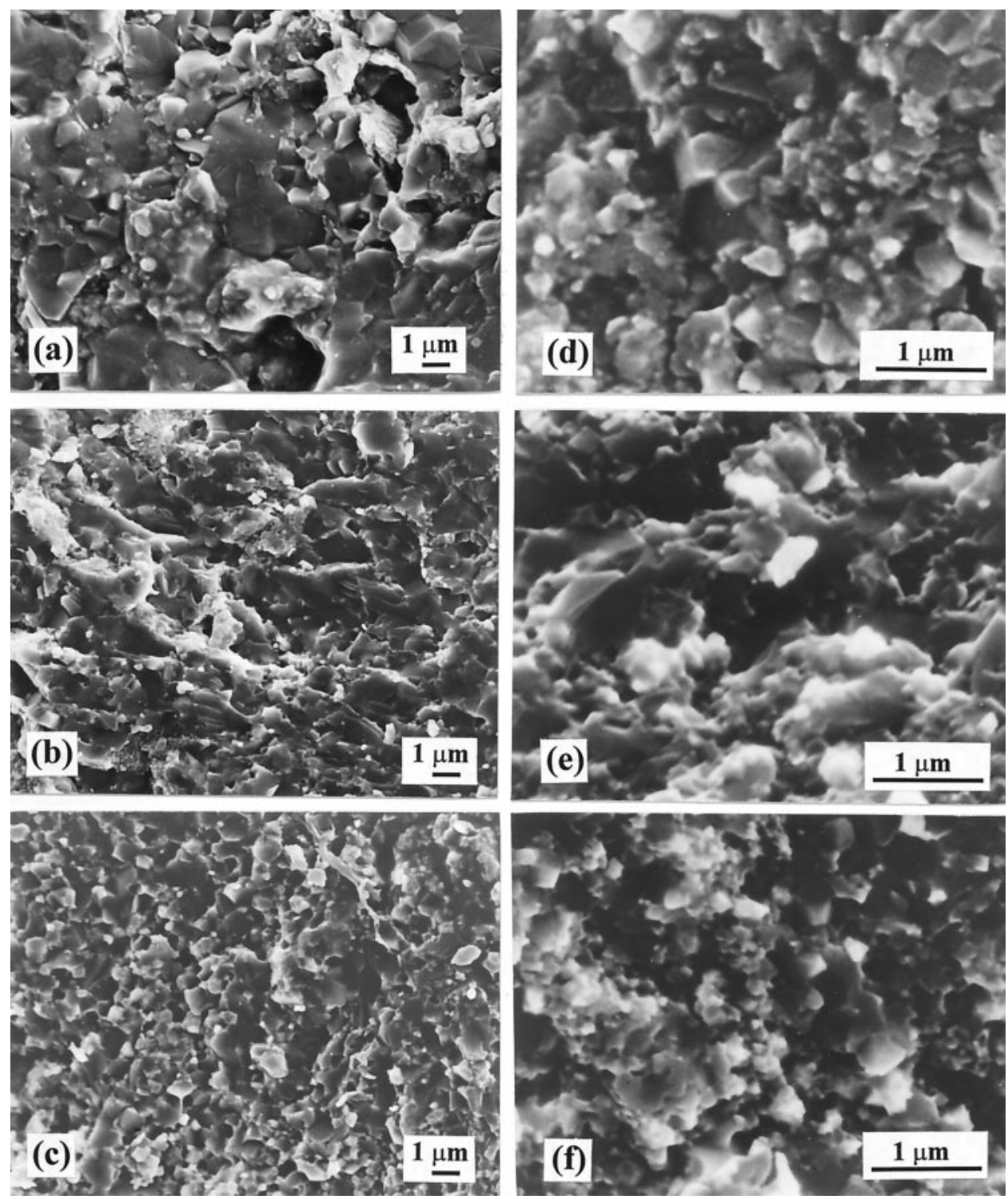

Fig. 4. SEM images of fracture surfaces of (a) BM0, (b) BM5, (c) BM30, (d) A0, (e) A5, and (f) A30.

in the unground, $6 \mu \mathrm{m}$-ground, and silica-polished specimens [13]. Thus, it is inferred that there are no compressive surface stresses contributing to the reinforcement.

SEM observation of the fractures of the pure $\mathrm{MgAl}_{2} \mathrm{O}_{4}$ specimens reveals a mixture of intergranular and transgranular fractures in BM0 (Fig. 4a), whereas they are almost totally intergranular in A0 (Fig. 4d). This could indicate that the critical size under which the fractures are totally intergranular ranges between 0.3 and $1.4 \mu \mathrm{m}$ (the average grain sizes of BM0 and A0, respectively), which is much lower than the $80-100 \mu \mathrm{m}$ range reported by White and Kelkar [6]. The fractures of the BM composites (Fig. 4b and c) are similar to those 
of BM0 (mixed intergranular and transgranular). However, the transgranular character of the fractures is lessened for the higher $\mathrm{ZrO}_{2}$ content (BM30 in Fig. 4c). In contrast, the fractures of the A composites (Fig. $4 \mathrm{e}$ and $\mathrm{f}$ ) are not totally identical to that of A0, because some degree of transgranular fracturing is observed. Thus, it appears that the dispersion of $\mathrm{ZrO}_{2}$ particles could induce some transgranular character to the fracturing in the composites with very small matrix grains $(0.3 \mu \mathrm{m}$ for A specimens $)$.

\section{Conclusions}

The room-temperature mechanical properties (fracture strength, fracture toughness, and Vickers microhardness) of $\mathrm{MgAl}_{2} \mathrm{O}_{4}$ and $\mathrm{x}$ wt $\% \mathrm{ZrO}_{2}-\mathrm{MgAl}_{2} \mathrm{O}_{4}(1 \leq \mathrm{x} \leq 30)$ hot-pressed materials were investigated. Compared to the unreinforced spinel, a twofold (or greater) increase in both strengthening and toughening is measured for materials with the highest zirconia content $\left(30 \mathrm{wt} \%\right.$ ). The presence of $\mathrm{m}-\mathrm{ZrO}_{2}$ and $\mathrm{t}-\mathrm{ZrO}_{2}$ in these composites suggests that both the microcracking and stress-induced $\mathrm{t} \rightarrow \mathrm{m}$ transformation mechanisms are active simultaneously. While strengthening and toughening are generally only modest for low zirconia contents, it was found that dispersing only $1 \mathrm{wt} \%$ of zirconia in the spinel produces a marked increase in the Vickers microhardness. Two kinds of materials were investigatedthose prepared from ball-milled powders, and those prepared from attrited powders. Differences in matrix grain sizes and in the proportions of tetragonal and monoclinic zirconia between one series of specimens and the other could explain some differences observed in the fracture behavior (transgranular, intergranular, or mixed) and in the mechanical properties. However, the total zirconia content appears to be a key parameter.

\section{References}

[1] H. Palmour III, D.M. Choi, L.D. Barnes, R.D. McBrayer, W.W. Kriegel, Mater Sci Res 1 (1963) 158.

[2] R.L. Stewart, R.C. Bradt, J Am Ceram Soc 63 (1980) 619.

[3] R.L. Stewart, M. Isawa, R.C. Bradt, J Am Ceram Soc 64 (1981) C-22.

[4] M. Sakai, R.C. Bradt, A.S. Kobayashi, J Ceram Soc Jpn Int Ed 96 (1988) 510.

[5] A. Gosh, K.W. White, M.G. Jenkins, A.S. Kobayashi, R.C. Bradt, J Am Ceram Soc 74 (1991) 1624.

[6] K.W. White, G.P. Kelkar, J Am Ceram Soc 75 (1992) 3440.

[7] C. Baudin, R. Martinez, P. Pena, J Am Ceram Soc 78 (1995) 1857.

[8] R.W. Rice, C.C.M. Wu, J Mater Sci Lett 14 (1995) 723.

[9] J. Wang, R. Stevens, J Mater Sci 24 (1989) 3421.

[10] N. Claussen, M. Rühle, in: Advanced Ceramics Vol. 3, Science and Technology of Zirconia, American Ceramics Society, Westerville, OH, 1981, p. 137.

[11] M. Fujita, H. Yoshimatsu, A. Osaka, Y. Miura, J Ceram Soc Jpn Int Ed 103 (1994) 81.

[12] S.H. Hyun, W.S. Song, J Mater Sci 31 (1996) 2457.

[13] O. Quénard, Ch. Laurent, A. Peigney, A. Rousset, Mater Res Bull 35 (12) (2000) in press.

[14] W.F. Brown, J.E. Srawley, ASTM Spec Tech Pub 410, ASTM, Philadelphia, PA, USA, 1966.

[15] B. Hallstedt, J Am Ceram Soc 75 (1992) 1497.

[16] S. Hori, M. Yoshimura, S. Somiya, J Am Ceram Soc 69 (1986) 169.

[17] M. Rühle, N. Claussen, A.H. Heuer, J Am Ceram Soc 69 (1986) 195. 